FIT(P)PTOLOGI
I N D ONES I A
ISSN: 2339-2479

\title{
Pengelolaan Penyakit Kuning pada Tanaman Lada oleh Petani di Wilayah Bangka
}

\author{
Management of Yellow Diseases on Pepper by \\ Farmers in Bangka Region
}

Abdul Munif*, Ita Sulistiawati
Institut Pertanian Bogor, Bogor 16680

\begin{abstract}
ABSTRAK
Penyakit kuning pada tanaman lada yang disebabkan oleh nematoda parasit tumbuhan hingga kini masih menjadi masalah utama pada pertanaman lada di wilayah Bangka. Kehilangan hasil berupa penurunan produksi lada yang diakibatkan oleh penyakit kuning cukup besar. Penelitian ini bertujuan memperoleh informasi mengenai pengetahuan, sikap dan tindakan petani dalam pengelolaan penyakit kuning pada tanaman lada di Kabupaten Bangka, Bangka Tengah dan Bangka Selatan. Penelitian ini meliputi dua kegiatan, yaitu survei tingkat kejadian penyakit kuning pada pertanaman lada di lapangan dan wawancara dengan petani lada. Hasil survei menunjukkan bahwa tingkat kejadian penyakit kuning sudah merata dan menyerang hampir semua lahan yang diamati. Hampir semua petani responden menyatakan bahwa penyakit kuning merupakan penyakit utama yang sangat merusak pertanaman lada. Tingkat pemahaman petani terhadap penyebab, gejala dan ekologi penyakit kuning dan cara-cara pengendaliannya masih sangat terbatas. Tindakan pengendalian yang dilakukan oleh petani terhadap penyakit kuning ialah pencabutan dan pembakaran tanaman terserang, dan pemberian kapur. Beberapa petani tidak melakukan tindakan pengendalian, namun sebagian besar petani menggunakan pestisida. Penggunaan pestisida untuk pengendalian penyakit kuning oleh petani belum sepenuhnya mengikuti prinsip pengendalian hama terpadu. Masih rendahnya pemahaman petani terhadap penyakit kuning mengakibatkan semakin sulit bagi petani untuk melakukan pengendaliannya.
\end{abstract}

Kata kunci: nematoda, pengendalian penyakit, pestisida, Piper nigrum

\begin{abstract}
Yellow disease caused by plant-parasitic nematodes are still a major problem on pepper production area in Bangka region. Significant yield losses occurred due to yellow disease. The objective of this research was to survey the yellow disease incidence and to study farmer's knowledge, attitude and practices on the management of yellow disease of black pepper in Bangka district, Central Bangka and South Bangka. This study consisted of a survey of the incidence of yellow disease in the field and interviews to the farmers. The result showed that the yellow disease had infected nearly all of black pepper fields in the areas with incidence of as much as 20-60\%. Almost all of the respondents reported that the yellow disease was the major disease of black pepper in Bangka region. Farmers' level of knowledge about the causal of disease, symptoms, ecology and control methods of the yellow disease are still very limited. Various control measures have been done by farmers to combat the disease, especially by removing and burning the infected plants or by application of lime. A few farmers did not even controlling the disease. Pesticides have been used by a few farmers to control the yellow disease, but the application of pesticide does not in line with integrated pest management principles.
\end{abstract}

Key words: disease control, nematode, pesticide, Piper nigrum

*Alamat penulis korespondensi: Departemen Proteksi Tanaman, Fakultas Pertanian, Institut Pertanian Bogor, Jalan Kamper, Kampus Darmaga, Bogor 16680

Tel: 0251-8629364, Faks: 0251-8629362, Surel: abdulmunif@ipb.ac.id 


\section{PENDAHULUAN}

Lada (Piper nigrum) merupakan jenis rempah yang paling sering digunakan di Eropa dibandingkan dengan rempah-rempah lainnya. Daerah utama penghasil lada di Indonesia ialah daerah Lampung yang terkenal sebagai penghasil lada hitam atau lampung black pepper dan Bangka yang terkenal sebagai penghasil lada putih atau muntok white pepper. Daras dan Pranowo (2009) melaporkan bahwa Indonesia masih menjadi salah satu produsen lada yang diperhitungkan di pasar dunia, namun produktivitas lada nasional terus menurun dalam sepuluh tahun terakhir. Faktor yang mempengaruhi produksi lada ialah gangguan penyakit, antara lain penyakit busuk pangkal batang yang disebabkan oleh Phytophthora capsici dan penyakit kuning yang disebabkan oleh nematoda (Manohara et al. 2006).

Penyakit kuning merupakan salah satu penyakit penting pada pertanaman lada di wilayah Bangka. Penyakit kuning sangat merugikan karena dapat menyebabkan tanaman lada berhenti berkembang sehingga menurunkan hasil panen. Penyakit ini dilaporkan merusak pertanaman lada wilayah Bangka hingga 32\%. Penyebab penyakit tersebut adalah nematoda Meloidogyne incognita dan Radopholus similis (Mustika 1990). Deteksi awal penyakit ini relatif sulit, biasanya tanaman diketahui sakit setelah menampakkan gejala menguning pada daun. Perkembangan penyakit tanaman sangat bergantung pada banyak faktor, baik lingkungan, tanaman, maupun teknik budi daya yang digunakan. Teknik atau sistem budi daya yang digunakan petani diduga berpengaruh terhadap perkembangan penyakit kuning pada pertanaman lada.

Penggunaan bahan kimia dalam pertanian di Indonesia, terutama pestisida untuk tujuan pengendalian hama dan penyakit tanaman masih merupakan cara yang paling disukai oleh petani. Pada komoditas tertentu pengeluaran petani untuk membeli pestisida dapat mencapai $40 \%$ dari total biaya produksi keseluruhan. Penggunaan pestisida yang terlalu intensif di lapang dapat berakibat tidak baik, seperti kerancunan, kontaminasi racun pestisida pada air sumur, bahan makanan dan kolam ikan, serta munculnya hama dan patogen yang resisten terhadap suatu pestisida. Alternatif pengendalian hama dan penyakit tanaman yang ramah lingkungan untuk mendukung kehidupan yang lebih sehat perlu terus dikembangkan sejalan dengan konsep pengendalian hama terpadu (PHT).

Penelitian ini bertujuan memperoleh informasi mengenai pengetahuan, sikap dan tindakan petani dalam pengelolaan tanaman lada dan pengelolaan penyakit khususnya penyakit kuning di wilayah Bangka.

\section{BAHAN DAN METODE}

Penelitian dilaksanakan di Desa Petaling, Kemuja, dan Cengkong Abang, Kecamatan Mendo Barat, Kabupaten Bangka; Desa Sungkap, Celuak, dan Teru, Kecamatan Simpang Katis, Kabupaten Bangka Tengah; dan Desa Delas, Nyelanding dan Air Gegas, Kecamatan Air Gegas, Kabupaten Bangka Selatan. Penelitian dilaksanakan dari bulan April sampai Juni 2010 dan bulan Agustus sampai Desember 2011.

\section{Metode Penelitian}

Penelitian ini terdiri atas dua kegiatan, yaitu survei kejadian penyakit kuning di lapangan dan wawancara dengan petani lada. Kegiatan survei lapangan bertujuan menentukan tingkat kejadian dan luas serangan penyakit kuning pada lada di lahan petani, sedangkan wawancara dengan petani dimaksudkan untuk memperoleh informasi sistem pengelolaan atau pengendalian penyakit kuning oleh petani.

\section{Survei Penyakit Kuning}

Pengamatan penyakit kuning dilakukan pada lahan tanaman lada milik petani di tiga kabupaten, yaitu Kabupaten Bangka, Bangka Tengah, dan Bangka Selatan. Setiap kabuapten diambil satu kecamatan dan dari setiap kecamatan dipilih 3 desa. Setiap desa dipilih 4 kebun lada yang ditentukan secara purposif dengan kriteria kebun mempunyai 
tanaman lada paling sedikit 2000 tanaman dan umur lada antara 1-2 tahun. Penentuan umur tanaman 1-2 tahun dengan alasan gejala awal penyakit kuning sudah terlihat saat tanaman berumur 1 tahun setelah di lapangan. Pada setiap lahan diamati 25 tanaman contoh yang ditentukan secara sistematis. Penilaian gejala penyakit kuning pada lada mengacu pada gejala umum di lapangan. Gejala awal penyakit kuning, yaitu daun tanaman lada berwarna kuning atau pucat dan daun menggulung ke arah batang, sedangkan gejala lanjut berupa tanaman menguning, kerdil, tunas mati, dan akhirnya seluruh daun gugur (Mustika 1990).

Tanaman lada yang menunjukkan gejala penyakit kuning, baik gejala masih awal atau gejala lanjut dianggap tanaman sudah terserang secara keseluruhan. Selanjutnya jumlah tanaman contoh yang terserang dicatat untuk menentukan kejadian penyakit kuning pada lahan tersebut. Kejadian penyakit dihitung dengan rumus:

$$
\text { Kejadian penyakit }=\frac{\mathrm{n}}{\mathrm{N}} \times 100 \% \text {, dengan }
$$

$\mathrm{n}$, jumlah tanaman yang terserang penyakit kuning; N, jumlah tanaman yang diamati.

\section{Wawancara dengan Petani}

Wawancara dengan petani dimaksudkan untuk mendapatkan gambaran tentang pengetahuan dan tindakan pengendalian terhadap penyakit kuning pada tanaman lada yang dilakukan petani responden. Wawancara secara langsung dilakukan terhadap petani lada di Kabupaten Bangka, Bangka Tengah, dan Bangka Selatan dengan menggunakan kuisioner. Dari setiap kabupaten ditentukan 40 responden yang menyebar di tiga desa sehingga jumlah total responden dari ketiga kabupaten adalah 120 petani responden. Petani responden dari tiap desa ditentukan secara purposif dengan kriteria petani tersebut menanam lada dalam tiga tahun terakhir dan memiliki tanaman lada saat wawancara. Data yang dikumpulkan meliputi karakteristik petani responden (tingkat pendidikan, umur, kepemilikan lahan, luas lahan garapan, pengalaman bertani lada) dan pengetahuan, sikap dan tindakan petani dalam pengelolaan tanaman lada (pemilihan bibit, pengolahan lahan, pengetahuan terhadap penyebab dan gejala penyakit kuning, teknik-teknik pengendalian penyakit kuning yang sudah digunakan dan berikut alasannya serta kendala yang dihadapi petani dalam pengendalian penyakit kuning selama ini). Data yang diperoleh dianalisis menggunakan program Microsoft Excel.

\section{HASIL}

Hasil survei menunjukkan rata-rata kejadian penyakit kuning pada tanaman lada di Kabupaten Bangka, Bangka Tengah dan Bangka Selatan berkisar antara 33\% dan 41\% (Tabel 1). Persentase kejadian penyakit kuning paling tinggi ditemukan 40\% di Desa Petaling Kabupaten Bangka, 60\% di Desa Sungkap Kabupaten Bangka Tengah, dan 48\% di Desa Nyelanding Kabupaten Bangka Selatan. Kejadian penyakit ini tergolong tinggi, diduga berkaitan dengan umur tanaman lada yang diamati relatif masih muda, yaitu baru berumur 2 tahun dan belum berproduksi. Contoh akar dari tanaman lada yang terinfeksi penyakit kuning menunjukkan lada yang membengkak yang merupakan gejala serangan nematoda Meloidogyne spp. dan sebagian lagi akar membusuk yang merupakan gejala serangan nematoda $R$. similis yang sudah lanjut.

Hasil survei menunjukkan bahwa lada masih merupakan komoditas yang banyak diusahakan oleh petani di wilayah Bangka. Umumnya petani menanam lada pada lahan milik sendiri atau milik keluarga dan sebagian lagi dengan menyewa lahan milik petani lain. Rata-rata luasan lahan tanaman lada antara 1-2 ha walaupun sebagian besar terutama di wilayah Bangka Selatan 50\% petani responden memiliki lahan tanaman lada lebih dari 2 ha. Sebagian besar lada ditanam dengan pola tumpang sari dengan tanaman karet atau kelapa sawit, namun akhir-akhir ini petani kembali menanam dengan pola monokultur (Tabel 2). Lebih dari 70\% varietas lada yang ditanam oleh petani di wilayah Bangka adalah varietas Lampung Daun Lebar (LDL), dan sisanya adalah varietas Merapin dan Jambi.

Hampir semua petani responden menyatakan bahwa gangguan hama dan 
Tabel 1 Rata-rata persentase kejadian penyakit kuning pada tanaman lada di Kabupaten Bangka, Bangka Tengah, dan Bangka Selatan

\begin{tabular}{llcc}
\hline Kabupaten & Desa pengamatan & $\begin{array}{c}\text { Persentase kejadian } \\
\text { penyakit (\%) }\end{array}$ & $\begin{array}{c}\text { Rata-rata kejadian } \\
\text { penyakit (\%) }\end{array}$ \\
\hline Bangka & Petaling & 48 & 33.33 \\
& Kemuja & 24 & \\
Bangka Tengah & Cengkong Abang & 28 & 30.67 \\
& Sungkap & 60 & \\
& Celuak & 20 & 41.33 \\
Bangka Selatan & Teru & 16 & \\
& Air Gegas & 44 & \\
& Delas & 32 & \\
& Nyelanding & 48 & \\
\hline
\end{tabular}

Tabel 2 Karakteristik budi daya lada oleh petani responden di Kabupaten Bangka, Bangka Tengah, dan Bangka Selatan

\begin{tabular}{|c|c|c|c|c|c|c|}
\hline \multirow{2}{*}{ Peubah } & \multicolumn{2}{|c|}{ Bangka } & \multicolumn{2}{|c|}{ Bangka Tengah } & \multicolumn{2}{|c|}{ Bangka Selatan } \\
\hline & $\begin{array}{l}\text { Jumlah } \\
\text { petani }\end{array}$ & Persen & $\begin{array}{l}\text { Jumlah } \\
\text { petani }\end{array}$ & Persen & $\begin{array}{l}\text { Jumlah } \\
\text { petani }\end{array}$ & Persen \\
\hline \multicolumn{7}{|l|}{ Luasan tanaman lada } \\
\hline$<1$ ha & 9 & 22.5 & 6 & 15.0 & 4 & 10.0 \\
\hline $1-2$ ha & 27 & 67.5 & 19 & 47.5 & 16 & 40.0 \\
\hline$>2 \mathrm{ha}$ & 4 & 10.0 & 15 & 37.5 & 20 & 50.0 \\
\hline \multicolumn{7}{|l|}{ Pola tanaman lada } \\
\hline Monokultur & 7 & 17.5 & 8 & 20.0 & 20 & 50.0 \\
\hline Tumpangsari & 33 & 82.5 & 32 & 80.0 & 20 & 50.0 \\
\hline \multicolumn{7}{|c|}{ Varietas lada yang ditanam } \\
\hline LDL (Lampung) & 30 & 75.0 & 31 & 77.5 & 30 & 75.0 \\
\hline Merapin & 5 & 12.0 & 9 & 32.5 & 10 & 25.0 \\
\hline Jambi & 5 & 12.0 & 0 & 0.0 & 0 & $0 . .0$ \\
\hline \multicolumn{7}{|c|}{ Penggunaan pupuk organik } \\
\hline Ya & 15 & 37.5 & 23 & 57.5 & 20 & 50.0 \\
\hline Tidak & 25 & 62.5 & 17 & 42.5 & 20 & 50.0 \\
\hline \multicolumn{7}{|c|}{ Penggunaan pupuk sintetik } \\
\hline NPK & 40 & 100 & 40 & 100 & 40 & 100 \\
\hline Urea & 20 & 50 & 17 & 42.5 & 13 & 32.5 \\
\hline TSP & 0 & 0 & 0 & 0.0 & 12 & 30.0 \\
\hline $\mathrm{KCl}$ & 0 & 0 & 0 & 0.0 & 6 & 15.0 \\
\hline
\end{tabular}

penyakit merupakan masalah utama dalam budi daya lada di Bangka bahkan lebih penting dari modal (Tabel 3). Menurut petani penyakit kuning merupakan penyakit yang paling merusak tanaman lada dan merugikan petani. Namun ternyata pengetahuan petani tentang penyakit kuning masih tergolong sangat kurang. Beberapa petani menduga bahwa penyebab penyakit kuning adalah cendawan, pupuk, asal bibit, air, dan tanah yang tidak subur, namun sebagian besar petani tidak mengetahui penyebab pasti penyakit ini (Tabel 3).
Petani responden pada umumnya mengetahui gejala penyakit kuning, yaitu berupa perubahan warna tanaman menjadi kuning, namun belum mengetahui secara pasti tahapan perkembangan gejala penyakit ini. Beberapa petani mengira bahwa gejala menguning pada tanaman merupakan hal yang biasa terjadi di lapangan sehingga beberapa petani membiarkannya saja, tetapi sebagian melakukan tindakan pengendalian (Tabel 4). Pengendalian penyakit kuning yang banyak dilakukan oleh petani tidak hanya dengan 
Tabel 3 Gangguan hama dan penyakit pada pertanaman lada di Kabupaten Bangka, Bangka Tengah, dan Bangka Selatan menurut petani responden

\begin{tabular}{|c|c|c|c|c|c|c|}
\hline \multirow[b]{2}{*}{ Peubah } & \multicolumn{2}{|c|}{ Bangka } & \multicolumn{2}{|c|}{ Bangka Tengah } & \multicolumn{2}{|c|}{ Bangka Selatan } \\
\hline & $\begin{array}{l}\text { Jumlah } \\
\text { petani }\end{array}$ & $\%$ & $\begin{array}{l}\text { Jumlah } \\
\text { petani }\end{array}$ & $\%$ & $\begin{array}{l}\text { Jumlah } \\
\text { petani }\end{array}$ & $\%$ \\
\hline \multicolumn{7}{|c|}{$\begin{array}{l}\text { Permasalahan utama usaha } \\
\text { tani lada }\end{array}$} \\
\hline Hama dan penyakit & 34 & 85.0 & 38 & 95.0 & 36 & 90.0 \\
\hline Modal usaha & 6 & 15.0 & 2 & 5.0 & 4 & 10.0 \\
\hline \multicolumn{7}{|c|}{$\begin{array}{l}\text { Penyakit utama lada yang } \\
\text { paling merugikan }\end{array}$} \\
\hline Penyakit kuning & 37 & 92.5 & 38 & 95.0 & 40 & 100 \\
\hline Penyakit Busuk & 2 & 5.0 & 9 & 22.5 & 4 & 10.0 \\
\hline pangkal batang & 1 & 2.5 & 9 & 22.5 & 11 & 27.5 \\
\hline Penyakit oleh virus & & & & & & \\
\hline \multicolumn{7}{|c|}{ Penyebab penyakit kuning } \\
\hline Tidak tahu & 30 & 75.0 & 25 & 62.5 & 28 & 70.0 \\
\hline Asal dari bibit & 1 & 2.5 & 4 & 10.0 & 4 & 10.0 \\
\hline Asal dari air & 0 & 0 & 6 & 15.0 & 0 & 0.0 \\
\hline Asal dari pupuk & 3 & 7.5 & 0 & 0.0 & 0 & 0.0 \\
\hline Asal dari tanah & 3 & 7.5 & 5 & 12.5 & 8 & 20.0 \\
\hline Jenis jamur & 3 & 7.5 & 0 & 0.0 & 0 & 0.0 \\
\hline
\end{tabular}

Tabel 4 Beberapa teknik pengendalian terhadap penyakit kuning pada lada yang dilakukan oleh petani responden

\begin{tabular}{|c|c|c|c|c|c|c|}
\hline \multirow[b]{2}{*}{ Peubah } & \multicolumn{2}{|c|}{ Bangka } & \multicolumn{2}{|c|}{ Bangka Tengah } & \multicolumn{2}{|c|}{ Bangka Selatan } \\
\hline & $\begin{array}{l}\text { Jumlah } \\
\text { petani }\end{array}$ & $\%$ & $\begin{array}{l}\text { Jumlah } \\
\text { petani }\end{array}$ & $\%$ & $\begin{array}{l}\text { Jumlah } \\
\text { petani }\end{array}$ & $\%$ \\
\hline \multirow{2}{*}{\multicolumn{7}{|c|}{$\begin{array}{l}\text { Sikap petani terhadap penyakit } \\
\text { kuning }\end{array}$}} \\
\hline & & & & & & \\
\hline Dibiarkan & 10 & 25.0 & 8 & 20.0 & 4 & 15.0 \\
\hline Dikendalikan & 30 & 75.0 & 32 & 80.0 & 36 & 90.0 \\
\hline \multicolumn{7}{|l|}{$\begin{array}{l}\text { Cara pengendalian terhadap } \\
\text { penyakit kuning yang pernah } \\
\text { dilakukan* }\end{array}$} \\
\hline Dicabut dan diganti & 12 & 30.0 & 0 & 0.0 & 4 & 10.0 \\
\hline Pemberian kapur & 10 & 25.0 & 20 & 50.0 & 12 & 30.0 \\
\hline Pestisida sintetik & 30 & 75.0 & 32 & 80.0 & 34 & 85.0 \\
\hline $\begin{array}{l}\text { Tanah bekas penyakit } \\
\text { dibakar }\end{array}$ & 2 & 5.0 & 0 & 0.0 & 0.0 & 0.0 \\
\hline $\begin{array}{l}\text { Pemberian tanah atau } \\
\text { bahan bekas pembakaran }\end{array}$ & 8 & 20.0 & 4 & 10.0 & 2 & 5.0 \\
\hline Aplikasi vapam & 0 & 0.0 & 0 & 0.0 & 2 & 5.0 \\
\hline Aplikasi bahan organik & 3 & 7.5 & 3 & 7.5 & 0.0 & 0.0 \\
\hline
\end{tabular}

*Petani responden bisa memilih atau memberikan jawaban lebih dari satu

menggunakan pestisida sintetik, namun aplikasi jenis fungisida vapam (Tabel 4). Cara juga beberapa cara pengendalian lainnya, pengendalian penyakit kuning yang paling seperti penambahan kapur, pencabutan dan banyak dilakukan oleh petani responden ialah pembakaran tanaman terinfeksi, pemberian menggunakan pestisida sintetik (Tabel 5). tanah bakar, aplikasi bahan organik sampai 
Tabel 5 Sikap petani responden dalam menggunakan pestisida sintetik untuk mengendalikan penyakit kuning

\begin{tabular}{|c|c|c|c|c|c|c|}
\hline \multirow{2}{*}{ Paramater yang diamati } & \multicolumn{2}{|c|}{ Bangka } & \multicolumn{2}{|c|}{ Bangka Tengah } & \multicolumn{2}{|c|}{ Bangka Selatan } \\
\hline & $\begin{array}{l}\text { Jumlah } \\
\text { petani }\end{array}$ & $\%$ & $\begin{array}{l}\text { Jumlah } \\
\text { petani }\end{array}$ & $\%$ & $\begin{array}{l}\text { Jumlah } \\
\text { petani }\end{array}$ & $\%$ \\
\hline \multicolumn{7}{|l|}{$\begin{array}{l}\text { Dasar dalam penggunaan } \\
\text { pestisida }\end{array}$} \\
\hline Terjadwal & 3 & 10.0 & 10 & 31.3 & 10 & 29.4 \\
\hline Adanya gejala & 21 & 70.0 & 18 & 56.2 & 10 & 29.4 \\
\hline $\begin{array}{l}\text { Tingkat kejadian } \\
\text { penyakit }\end{array}$ & 6 & 20.0 & 4 & 12.5 & 14 & 41.2 \\
\hline \multicolumn{7}{|l|}{ Aplikasi pestisida } \\
\hline $\begin{array}{l}\text { Jenis yang sama } \\
\text { dengan konsentrasi } \\
\text { yang sama }^{\mathrm{a}}\end{array}$ & 10 & 33.3 & 14 & 43.7 & 10 & 29.4 \\
\hline $\begin{array}{l}\text { Jenis sama dengan } \\
\text { konsentrasi ditingkatkan }\end{array}$ & 18 & 60.0 & 14 & 43.7 & 12 & 35.3 \\
\hline Pestisida baru ${ }^{\mathrm{c}}$ & 2 & 6.7 & 4 & 12.6 & 12 & 35.3 \\
\hline
\end{tabular}

Hasil wawancara dengan petani responden juga memperlihatkan bahwa petani masih tetap bersemangat untuk menanam lada, walaupun banyak gangguan penyakit kuning. Petani beralasan bahwa walaupun tanaman terserang penyakit kuning, tetapi masih tetap bisa berproduksi asalkan dilakukan pemupukan dan perawatan yang baik. Sebagian petani responden yakin bahwa penyakit kuning ini masih bisa dikendalikan karena suatu saat akan ada teknologi untuk mengendalikan penyakit kuning, walaupun sebagian petani beranggapan sebaliknya (Tabel 6).

\section{PEMBAHASAN}

Persentase kejadian penyakit kuning pada tanaman lada menunjukkan tingkat serangan yang stabil tinggi. Mustika (2005) mengungkapkan pada pengamatan terhadap tingkat serangan penyakit kuning yang dilakukan pada tahun 1987 menunjukkan bahwa rata-rata kerusakan tanaman lada di wilayah Bangka yang disebabkan oleh penyakit kuning ialah sebesar $32 \%$. Tingginya persentase kejadian penyakit kuning ini diduga dipengaruhi oleh kadar air tanah. Mustika (1990) mengungkapkan pada tanah dengan kadar air 60\% kapasitas lapang, gejala penyakit kuning terjadi lebih awal dibandingkan dengan pada tanah dengan kadar air 100\% kapasitas lapang. Selain itu, persentase kejadian penyakit meningkat, diduga petani tidak melakukan pengendalian yang tepat dan tanaman yang terinfeksi dibiarkan di lapangan dengan anggapan tanaman masih bisa berproduksi.

Tanaman lada terinfeksi yang tetap dibiarkan di lahan dapat menyebabkan nematoda parasit penyebab penyakit kuning akan terus berkembang biak sehingga populasinya meningkat dan berpotensi sebagai sumber inokulum penyakit kuning pada lahan tersebut. Kadar air tanah sekitar $60 \%$ diduga sangat sesuai untuk perkembangan nematoda parasit dan perkembangan penyakit kuning (Mustika 2005).

Jenis lada yang banyak ditanam oleh petani di wilayah Bangka ialah varietas LDL. Varietas LDL memiliki produktivitas tinggi walaupun agak rentan terhadap penyakit kuning (Hamid dan Rahayuningsih 1990). Hampir semua petani responden melakukan pemupukan untuk tanaman lada terutama pupuk sintetik seperti NPK, namun tidak semua petani responden memberikan pupuk organik karena beberapa alasan, yaitu ketersediaannya yang terbatas dan kurang praktis dalam hal pengangkutan.

Selain penggunaan pestisida sintetik, pengendalian penyakit kuning yang banyak 
Tabel 6 Sikap dan tanggapan petani responden terhadap penyakit kuning pada lada

\begin{tabular}{|c|c|c|c|c|c|c|}
\hline \multirow{2}{*}{ Peubah } & \multicolumn{2}{|c|}{ Bangka } & \multicolumn{2}{|c|}{ Bangka Tengah } & \multicolumn{2}{|c|}{ Bangka Selatan } \\
\hline & $\begin{array}{l}\text { Jumlah } \\
\text { petani }\end{array}$ & Persen & $\begin{array}{l}\text { Jumlah } \\
\text { petani }\end{array}$ & Persen & $\begin{array}{l}\text { Jumlah } \\
\text { petani }\end{array}$ & Persen \\
\hline \multicolumn{7}{|c|}{ Apakah anda yakin penyakit } \\
\hline \multicolumn{7}{|c|}{ kuning dapat dikendalikan? } \\
\hline $\mathrm{Ya}$ & 8 & 20.0 & 28 & 70.0 & 18 & 45.0 \\
\hline Tidak & 32 & 80.0 & 12 & 30.0 & 22 & 55.0 \\
\hline \multicolumn{7}{|c|}{$\begin{array}{l}\text { Apakah anda yakin bahwa } \\
\text { pestisida/ fungsida dapat } \\
\text { mengendalikan penyakit } \\
\text { kuning? }\end{array}$} \\
\hline Ya & 22 & 55.0 & 20 & 50.0 & 18 & 45.0 \\
\hline Tidak & 18 & 45.0 & 20 & 50.0 & 22 & 55.0 \\
\hline \multicolumn{7}{|c|}{$\begin{array}{l}\text { Apakah anda akan tetap } \\
\text { menanam lada walaupun ada } \\
\text { masalah penyakit kuning? }\end{array}$} \\
\hline Ya & 38 & 95.0 & 36 & 90.0 & 39 & 97.5 \\
\hline Tidak & 2 & 5.0 & 4 & 10.0 & 1 & 2.5 \\
\hline \multicolumn{7}{|c|}{$\begin{array}{l}\text { Apakah anda yakin bahan } \\
\text { organik dapat mengendalikan } \\
\text { atau mengurangi penyakit } \\
\text { kuning? }\end{array}$} \\
\hline Ya & 18 & 45.0 & 23 & 57.5 & 32 & 80.0 \\
\hline Tidak & 22 & 55.0 & 17 & 42.5 & 8 & 20.0 \\
\hline \multicolumn{7}{|c|}{$\begin{array}{l}\text { Apakah anda yakin mikroba } \\
\text { (bakteri atau cendawan } \\
\text { antagonis) dapat mengendalikan } \\
\text { penyakit kuning? }\end{array}$} \\
\hline Ya & 4 & 10.0 & 14 & 35.0 & 12 & 30.0 \\
\hline Tidak & 4 & 10.0 & 10 & 25.0 & 4 & 10.0 \\
\hline Tidak tahu & 32 & 80.0 & 16 & 40.0 & 24 & 60.0 \\
\hline
\end{tabular}

dilakukan oleh petani ialah penambahan kapur, pencabutan dan pembakaran tanaman terinfeksi, pemberian tanah bakar, dan aplikasi bahan organik. Hal ini menunjukkan bahwa petani umumnya sudah mengembangkan cara pengendaliannya yang cukup beragam. Salah satu cara yang juga digunakan oleh petani setempat untuk menghindari penyakit kuning pada lada ialah mencari lahan baru dan tidak menggunakan lahan bekas lada. Hal ini didasarkan pada pengalaman petani lainnya.

Petani responden dalam menggunakan pestisida belum sepenuhnya tepat karena sebagian masih berdasarkan jadwal dan masih banyak yang dengan mudah meningkatkan konsentrasi penyemprotan jika dianggap belum efektif. Laba (2005) melaporkan bahwa petani masih mengandalkan insektisida sintetik untuk mengendalikan hama lada di Bangka dan penggunaannya semakin intensif terutama jika harga lada sedang tinggi. Elizabeth dan Hendayana (2009) juga melaporkan bahwa petani cenderung memilih pestisida untuk mengendalikan penyakit dan hama pada lada di Lampung. Penggunaan pestisida yang tinggi untuk pengendalian hama tanaman karena belum ditemukannya teknik pengendalian lain yang tepat dan rasional (Laba 2005).

Petani responden masih tetap bersemangat untuk menanam lada, walaupun adanya gangguan penyakit kuning. Beberapa teknik pengendalian dengan menggunakan bahan organik kompos dan mikrob endofit pada tanaman lada di rumah kaca menunjukkan hasil yang baik, yaitu dapat menurunkan infeksi jumlah puru yang disebabkan oleh 
nematoda Meloidogyne spp. dibandingkan dengan kontrol (Munif dan Harni 2012). Manohara dan Wahyuno (2009) juga melaporkan bahwa penggunaan bahan organik bungkil jarak dapat mengendalikan penyakit kuning dan penyakit busuk pangkal batang. Pengembangan pengendalian nematoda parasit berbasis pada komponen biologi dengan pemanfaatan bahan organik dan mikrob antagonis adalah teknik yang tepat karena lebih murah dan ramah lingkungan (Sikora 1992; Munif dan Kristina 2012).

Upaya untuk mengembangkan teknologi pengendalian penyakit kuning pada lada menghidupkan kelompok tani dan program sekolah lapang pengendalian hama terpadu (Elizabeth dan Hendayana 2009). Jumlah petani yang pernah mengikuti SLPHT lada masih sangat terbatas. Sebagian besar petani responden sangat mengharapkan adanya kegiatan penyuluhan dan pelatihan mengenai penyakit kuning dan cara pengendaliannya secara teratur maupun cara budi daya lada yang lebih baik daripada pihak pemerintah. Sebagian besar masih cukup aktif dalam kegiatan kelompok tani, terutama karena sangat diperlukan untuk memperoleh pembagian pupuk subsidi.

Penyakit kuning merupakan permasalahan utama petani dalam budi daya lada di wilayah Bangka. Terbatasnya informasi yang dimiliki oleh petani mengenai penyakit kuning menyebabkan perkembangan penyakit ini masih tetap tinggi. Sampai saat ini belum ditemukan strategi atau cara pengendalian penyakit kuning yang efektif. Evaluasi dan pengembangan teknologi pengendalian penyakit kuning yang efektif sangat diperlukan dalam rangka meningkatkan produktivitas lada khususnya di wilayah Bangka.

\section{UCAPAN TERIMA KASIH}

Penulis mengucapkan terima kasih kepada Badan Penelitian dan Pengembangan, Kementerian Pertanian, atas dukungan dana penelitian melalui program KKP3T.

\section{DAFTAR PUSTAKA}

Daras U, Pranowo D. 2009. Kondisi kritis lada putih Bangka Belitung dan alternatif pemulihannya. J Litbang Pert. 28(1):1-6.

Elizabeth R, Hendayana R. 2010. Peran dan peluang SL-PHT komoditi lada mempengaruhi kognitif petani perkebunan rakyat (Studi kasus: Propinsi Lampung). Bogor (ID): Pusat Penelitian Sosial Ekonomi Pertanian.

Hamid A, Rahayuningsih ST. 1990. Identifikasi dan pengenalan empat varietas utama tanaman lada. Di dalam: Simposium I Hasil Penelitian dan Pengembangan Tanaman Industri. Bogor (ID): Pusat Penelitian dan Pengembangan Tanaman Industri. hlm 586-590.

Laba IW. 2005. Kepik Renda lada, Doconocoris hewetti (Dist.) (Hemiptera: Tingidae): Biologi, kelimpahan populasi dan pengaruhnya terhadap kehilangan hasil [disertasi]. Bogor (ID): Institut Pertanian Bogor.

Manohara D, Wahid P, Wahyono D, Nuryani Y, Mustika I, Laba IW, Yuhono, Rivai AM, Saefudin. 2006. Status Teknologi Tanaman Lada. Di dalam: Prosiding Status Teknologi Tanaman Rempah dan Aneka Tanaman Industri; 200626 Sep; Parungkuda-Sukabumi (ID): Pusat Penelitian Tanaman Perkebunan, Deptan. hlm 1-54.

Manohara D, Wahyuno D. 2009. Kontroversi penggunaan bungkil jarak (Ricinus communis) pada penyakit busuk pangkal batang dan penyakit kuning tanaman lada. Warta Penel Pengembangan Tan Indust.15(2):1-3.

Munif A, Harni R. 2012. Keefektifan bakteri endofit untuk mengendalikan nematoda parasit Meloidogyne incognita pada tanaman lada. Bul Riset Tan Rempah Aneka Indust. 2(3):377-382.

Munif A, Kristiana. 2012. Hubungan bakteri endofit dan nematoda parasit penyebab penyakit kuning pada tanaman lada di 
provinsi Bangka Belitung. Bul RISTRI. 3(1):71-78.

Mustika I. 1990. Studies on the interaction of Meloidogyne incognita, Radopholus similis and Fusarium solani on black pepper (Piper nigrum L.). [disertasi]. Netherland (NL): Wageningen Agric.Univ.

Mustika I. 2005. Penyakit kuning pada tanaman lada dan cara pengendaliannya. Di dalam: Materi Pelatihan Teknologi Imunisasi Silang untuk Pengendalian
OPT Vanili, Lada dan Jambu Mete; 2005 Agu 22-26; Bogor (ID): Balai Penelitian Tanaman Rempah dan Obat dan Direktorat Perlindungan Perkebunan, Ditjen Perkebunan Deptan. hlm 28.

Sikora RA. 1992. Management of the antagonistic potential in agriculture system for the biological control of plant parasitic nematodes. Annu Rev Phytopathol. 30: 245-270. DOI: http://dx.doi.org/10.1146/ annu rev.py.30.090192.001333. 